J. Perinat. Med. $12(1984) 85$

\title{
Effects of diazoxide on maternal and fetal circulations in normotensive and hypertensive pregnant sheep
}

\author{
H.C. S. Wallenburg, J.P. J. A. Kuijken \\ Department of Obstetrics and Gynecology, \\ Erasmus University Medical School, Rotterdam, The Netherlands
}

Diazoxide, a nondiuretic benzothiadiazine derivative, administered as a bolus or infused slowly over prolonged periods, has a strong antihypertensive effect, due to relaxation of vascular smooth muscle in the precapillary resistance vessels [13]. For this reason, diazoxide is recommended for the management of hypertensive crises in pregnancy $[1,8,9,14,15,18,25,28]$. The antihypertensive activity of the drug appears to be associated with an increase in heart rate and cardiac output which could be advantageous for the maintenance of cerebral and renal blood flows $[12,25]$.

However, the objective to obtain rapid reduction of blood pressure in pregnant patients with severe hypertension in an effort to prevent damage to the maternal brain and kidneys is complicated by the desire to avoid adverse effects on the uteroplacental circulation leading to fetal compromise. To maintain, or preferably increase, uterine blood flow under a reduced arterial pressure would require reduction of uteroplacental vascular resistance. Some clinical data suggest that such an effect does not occur following an intravenous bolus of diazoxide, with the consequence of fetal distress [20, 23]. Other studies, however; conclude that immediate reduction of maternal arterial pressure is without apparent hazard to the fetus $[1,8,14,15,18]$ in particular when blood pressure is lowered gradually by slow infusion of diazoxide [28] or by intermittent administration of low doses [24].
For obvious reasons, the direct and indirect hemodynamic effects of diazoxide on the uteroplacental and fetal circulations cannot be assessed quantitatively in hypertensive women. Experimental studies in various species of pregnant animals have been reported in the literature but none of the animals were hypertensive $[3,6,16,17,21]$. Since an experimental model of renovascular hypertension, based on the GOLDBLATT-mechanism is available in pregnant sheep [5] the present study was designed to study the short-time maternal and fetal hemodynamic effects of a bolus injection of diazoxide in chronically instrumented normotensive and hypertensive pregnant ewes.

\section{Material and methods}

All experiments were done in chronically instrumented pregnant ewes with a gestational age of 105-113 days and a single fetus as demonstrated by X-ray examination. In six ewes one-kidney renal hypertension was induced by the GOLDBLATT-mechanism; these ewes constitu te Group $\mathrm{H}$. Five ewes served as controls (Group NH).

\subsection{Surgical procedures}

The ewes were starved for 12 hours prior to surgery. Surgical anesthesia was obtained with 60 per cent nitrous oxide and $0.5-4$ volume per 
cent enflurane in oxygen following tracheal intubation and mechanical ventilation. The ewes which were to become hypertensive (Group H) were placed in a lateral position and a kidney. was approached retroperitoneally through an oblique lumbar incision. The renal pedicle was divided between hemostats and the kidney was removed. A polyvinyl catheter was advanced into the descending aorta through the stump of the renal artery. The contralateral kidney was approached in the same manner through a contralateral lumbar incision. A calibrated electromagnetic flow transducer was placed around a portion of the renal artery, carefully cleaned of adhering tissue, and an inflatable cuff was fitted around the artery distal to the flow transducer.

In the control animals (Group NH) an electromagnetic flow transducer was fitted around a renal artery, the contralateral kidney was left untouched. A polyvinyl catheter was introduced into the descending aorta through a femoral artery. The arterial catheter and the cable of the flow transducer were tunneled subcutaneously to the flank of the ewe, in one-kidney animals together with the tubing from the inflatable cuff, and placed in a pouch.

Renal arterial blood flow and arterial pressure were monitored frequently after surgery. When values were considered to be stable, usually two to three days after surgery, renal blood flow in the one-kidney animals was reduced by approximately $30 \%$ by inflating the cuff around the renal artery with sterile oil. The animals were monitored daily and renal arterial constriction was adjusted to maintain $20-30 \%$ reduction in renal blood flow. No experiments were done with the control animals.

A second surgical procedure was performed in the one-kidney animals as well as in the controls under the same conditions one week after the first operation. A lower midline laparotomy was made, the pregnant uterine horn was exposed, and access to the fetus was obtained through a small myometrial window. A polyvinyl catheter was inserted into the fetal descending aorta through a femoral artery. An electromagnetic flow transducer was fitted around one umbilical artery close to the fetal abdominal wall or, in some cases, around the common umbilical artery via a retroperitoneal approach [2].

Finally, the fetus was equipped with ECG electrodes and the membranes and the uterine incision were closed. An electromagnetic flow transducer was placed around the main ascending branch of the uterine artery supplying the pregnant horn. All catheters and wires were brought out subcutaneously to the ewe's flank, and the abdominal incision was closed. Finally, a catheter was threaded into a maternal jugular vein through a small submandibular branch.

\subsection{Experiments}

Experiments were begun on the third day after the last operation, and repeated every second or third day. During the experiments the ewe was standing quietly in a specially designed movable cage. Flows, pressures and fetal ECG were continuously recorded. Fetal heart rate was derived from the ECG signal, maternal heart rate from the arterial pressure curve. All signals were recorded on a polygraph and stored on magnetic tape. Uterine, renal, and umbilical vascular resistances were calculated by dividing the mean arterial blood pressure by the blood flow in the uterine artery, the renal artery, and the umbilical artery, respectively.

Following a control period of at least 30 minutes during which stable signals were obtained, a dose of $300 \mathrm{mg}$ of diazoxide ${ }^{1}$ (approximately $5 \mathrm{mg}$ per $\mathrm{kg}$ of bodyweight) was administered intravenously as a bolus over a period of $30-60$ seconds. In a number of experiments the injection of diazoxide was combined with rapid venous infusion of a plasma expander ${ }^{2} ; 250 \mathrm{ml}$ were given just prior to the injection of diazoxide, and $250 \mathrm{ml}$ in the first five minutes following the injection. The fetal and maternal hemodynamic effects were recorded for at least two hours following injection. Samples of fetal and maternal arterial blood were drawn just prior to injection and 30 and 120 minutes following injection of diazoxide, for determination of blood gases and acid-base status.

\footnotetext{
1 HYPERSTAT (Essex)

2 HAEMACCEL (Behring)
} 
Following the second operation the number of animals available for study in both groups decreased progressively due to obstruction of catheters, transducer failure, development of malignant hypertension with uremia, and fetal death or premature delivery. A total of 17 experiments could be performed in the six one-kidney animals of group $\mathrm{H}$, nine with and eight without the use of plasma expander. In the five animals of group NH 10 experiments could be done, four with and six without plasma expansion.

All results are presented as means $\pm S$. D. throughout. Statistical analysis was done with appropriate nonparametric tests for paired and unpaired data, and $\mathrm{p}<0.05$ was chosen as the level of significance.

\section{Results}

In the one-kidney ewes (Group H) mean arterial pressure in the control period was $106 \pm 9 \mathrm{~mm} \mathrm{Hg}$; in the control group (Group NH) it was $75 \pm 8 \mathrm{~mm} \mathrm{Hg}$, which is significantly lower $(\mathrm{p}<0.01)$. Maternal heart rate was $114 \pm 23$ beats $\min ^{-1}$ in group $H$, which is significantly higher than that in group $\mathrm{NH}$ $\left(101 \pm 8\right.$ beats $\left.\min ^{-1}\right)$. Despite the fact that the constrictor around the renal artery in group $\mathrm{H}$ was adjusted daily to keep renal arterial blood flow reduced by $20-30$ per cent, the blood flow usually rebounded quickly and eventually mean renal arterial flow during the control periods in group $\mathrm{H}$ $\left(280 \pm 66 \mathrm{ml} \mathrm{min}^{-1}\right)$ was equal to that in group $\mathrm{NH}$ $\left(279 \pm 76 \mathrm{ml} \mathrm{min}^{-1}\right)$. However, due to the elevated arterial pressure, mean renal arterial resistance in group $\mathrm{H}\left(0.41 \pm 0.13 \mathrm{~mm} \mathrm{Hg} \mathrm{ml}^{-1} \mathrm{~min}\right)$ was significantly $(\mathrm{p}<0.01)$ higher than that in group $\mathrm{NH}$ $(0.28 \pm 0.1)$.

The actual values of blood flow in the main uterine artery showed marked differences between animals, both in group $\mathrm{H}$ and in group $\mathrm{NH}$, which.appeared to be due in part to variations in the localization of the flow transducer. Mean uterine artery flow was $255 \pm 114 \mathrm{ml} \mathrm{min}^{-1}$ in group $\mathrm{H}$ and $318 \pm 145$ in group $\mathrm{NH}$, resulting in a mean uterine vascular resistance of $0.42 \pm 0.2 \mathrm{~mm} \mathrm{Hg} \mathrm{ml}^{-1} \mathrm{~min}$ in group $\mathrm{H}$ and of $0.21 \pm 0.1$ in group $\mathrm{NH}(\mathrm{p}<0.05)$.
There were no differences between the groups with regard to fetal heart rate and fetal mean arterial pressure in the control periods.

Since umbilical arterial flow was measured in one umbilical artery in some animals and in the common umbilical artery in others, the actual values could not be compared. Mean values of fetal $\mathrm{pH}$ (7.39) and $\mathrm{pO}_{2}(21.0 \mathrm{~mm} \mathrm{Hg})$ were equal in both groups.

\subsection{Diazoxide without plasma expander}

Without the use of plasma expander, diazoxide caused a rapid and significant fall in maternal arterial pressure in both groups to approximately 50 per cent of control values (Tabs. I and II). The maximum decrease was obtained within 10 minutes after injection. In particular in group $\mathrm{H}$ the fall in diastolic pressure was more pronounced than that in systolic pressure, pulse pressure widened considerably. Two hours after injection mean arterial pressure had returned to control values in most normotensive ewes, but was still significantly lower in the hypertensive group. In both groups the fall in arterial pressure was accompanied by a significant increase in maternal heart rate, which was most pronounced in group $\mathrm{NH}$.

The relative changes in uterine and umbilical arterial flows and calculated vascular resistances are summarized in Tabs. III and IV. Uterine arterial flows fell significantly and in parallel with or somewhat steeper than the arterial pressures in both groups. This resulted in an increase in mean uterine vascular resistance which reached a significant level at 30-60 minutes in group $\mathrm{NH}$. In group NH renal arterial blood showed a variable response: In some cases it fell in parallel with the decrease in arterial pressure, but in other experiments there was evidence of autoregulation. In hypertensive ewes which received diazoxide without plasma expander, there was no evidence of autoregulation of the renal circulation; renal blood flow fell in parallel with the drop in arterial pressure. In both groups no significant changes were observed in fetal arterial pressure. Fetal heart rate started to fall within five minutes following administration of diazoxide to the ewe, and 
Tab. I. Maternal and fetal hemodynamic variables (mean \pm S.D.) in normotensive ewes, before and after intravenous administration of $300 \mathrm{mg}$ of diazoxide.

\section{Minutes after administration of diazoxide}

\begin{tabular}{|c|c|c|c|c|c|c|c|}
\hline & & $\begin{array}{l}\text { Control } \\
\text { period }\end{array}$ & $0-5$ & $6-10$ & $11-35$ & $36-60$ & $61-110$ \\
\hline $\begin{array}{l}\text { without plasma } \\
\text { expander }(n=6)\end{array}$ & $\begin{array}{l}\text { MHR } \\
\text { MAP } \\
\text { RAF } \\
\text { RVR } \\
\text { FHR } \\
\text { FAP }\end{array}$ & $\begin{aligned} 104 & \pm 20 \\
74 & \pm 8 \\
279 & \pm 95 \\
0.29 & \pm 0.11 \\
171 & \pm 22 \\
43 & \pm 4\end{aligned}$ & $\begin{aligned} 162 & \pm 21 \\
51 & \pm 14 \\
219 & \pm 115 \\
0.28 & \pm 0.13 \\
159 & \pm 36 \\
41 & \pm 1\end{aligned}$ & $\begin{aligned} 158 & \pm 30 \\
40 & \pm 13 \\
128 & \pm 38 \\
0.32 & \pm 0.10 \\
138 & \pm 31 \\
42 & \pm 6\end{aligned}$ & $\begin{aligned} 124 & \pm 18 \\
40 & \pm 10 \\
131 & \pm 49 \\
0.37 & \pm 0.17 \\
159 & \pm 35 \\
36 & \pm 4\end{aligned}$ & $\begin{aligned} 129 & \pm 20 \\
60 & \pm 27 \\
185 & \pm 40 \\
0.33 & \pm 0.15 \\
169 & \pm 16 \\
39 & \pm 4\end{aligned}$ & $\begin{aligned} 144 & \pm 9 \\
63 & \pm 28 \\
200 & \pm 29 \\
0.31 & \pm 0.10 \\
180 & \pm 11 \\
43 & \pm 1\end{aligned}$ \\
\hline $\begin{array}{l}\text { with plasma } \\
\text { expander }(n=4)\end{array}$ & $\begin{array}{l}\text { MHR } \\
\text { MAP } \\
\text { RAF } \\
\text { RVR } \\
\text { FHR } \\
\text { FAP }\end{array}$ & $\begin{aligned} 102 & \pm 3 \\
78 & \pm 6 \\
281 & \pm 100 \\
0.28 & \pm 0.01 \\
174 & \pm 17 \\
44 & \pm 9\end{aligned}$ & $\begin{aligned} 183 & \pm 36 \\
73 & \pm 2 \\
316 & \pm 75 \\
0.25 & \pm 0.05 \\
173 & \pm 13 \\
46 & \pm 6\end{aligned}$ & $\begin{aligned} 188 & \pm 33 \\
73 & \pm 6 \\
308 & \pm 54 \\
0.25 & \pm 0.02 \\
168 & \pm 6 \\
43 & \pm 12\end{aligned}$ & $\begin{aligned} 192 & \pm 10 \\
71 & \pm 3 \\
288 & \pm 50 \\
0.25 & \pm 0.01 \\
161 & \pm 2 \\
45 & \pm 10\end{aligned}$ & $\begin{aligned} 193 & \pm 30 \\
68 & \pm 12 \\
268 & \pm 41 \\
0.25 & \pm 0.03 \\
175 & \pm 18 \\
43 & \pm 8\end{aligned}$ & $\begin{aligned} 181 & \pm 26 \\
69 & \pm 11 \\
270 & \pm 48 \\
0.27 & \pm 0.03 \\
181 & \pm 26 \\
43 & \pm 10\end{aligned}$ \\
\hline
\end{tabular}

MHR Maternal Heart Rate (beats $\min ^{-1}$ )

MAP Maternal Mean Arterial Pressure (mm Hg)

RAF Renal Artery Flow $\left(\mathrm{ml} \mathrm{min}^{-1}\right)$

remained significantly decreased during the following 10-15 minutes. Blood flow in the umbilical artery showed a tendency to fall with a rise in umbilical vascular resistance, but the changes were not significant. Fetal $\mathrm{pH}$ showed an average maximum fall of 0.09 in both groups, and fetal arterial $\mathrm{pO}_{2}$ values were found to be decreased by $2-6 \mathrm{~mm} \mathrm{Hg}$ at 30 minutes after
RVR Renal Vascular Resistance ( $\mathrm{mm} \mathrm{Hg} \mathrm{ml}^{-1} \mathrm{~min}$ )

FHR Fetal Heart Rate (beats $\min ^{-1}$ )

FAP Fetal Mean Arterial Pressure (mm Hg)

Tab. II. Maternal and fetal hemodynamic variables (mean \pm S.D.) in hypertensive ewes before and after intravenous administration of $300 \mathrm{mg}$ of diazoxide.

Minutes after administration of diazoxide

\begin{tabular}{|c|c|c|c|c|c|c|c|}
\hline & & $\begin{array}{l}\text { Control } \\
\text { period }\end{array}$ & $0-5$ & $6-10$ & $11-35$ & $36-60$ & $61-110$ \\
\hline \multirow{6}{*}{$\begin{array}{l}\text { without plasma } \\
\text { expander }(n=8)\end{array}$} & MHR & $116 \pm 10$ & $154 \pm 12$ & $119 \pm 11$ & $129 \pm 19$ & $151 \pm 15$ & $154 \pm 17$ \\
\hline & MAP & $105 \pm 6$ & $64 \pm 12$ & $50 \pm 8$ & $75 \pm 15$ & $89 \pm 11$ & $91 \pm 8$ \\
\hline & RAF & $274 \pm 59$ & $200 \pm 68$ & $137 \pm 50$ & $196 \pm 77$ & $266 \pm 66$ & $287 \pm 66$ \\
\hline & RVR & $0.41 \pm 0.11$ & $0.37 \pm 0.14$ & $0.40 \pm 0.10$ & $0.45 \pm 0.18$ & $0.38 \pm 0.12$ & $0.33 \pm 0.10$ \\
\hline & FHR & $172 \pm 22$ & $166 \pm 25$ & $145 \pm 27$ & $190 \pm 17$ & $193 \pm 17^{\circ}$ & $199 \pm 14$ \\
\hline & FAP & $37 \pm 6$ & $36 \pm 5$ & $38 \pm 5$ & $40 \pm 4$ & $38 \pm 4$ & $38 \pm 4$ \\
\hline \multirow{6}{*}{$\begin{array}{l}\text { with plasma } \\
\text { expander }(n=9)\end{array}$} & MHR & $112 \pm 15$ & $173 \pm 23$ & $194 \pm 17$ & $194 \pm 17$ & $177 \pm 15$ & $160 \pm 21$ \\
\hline & MAP & $108 \pm 13$ & $95 \pm 13$ & $90 \pm 12$ & $88 \pm 10$ & $91 \pm 10$ & $96 \pm 15$ \\
\hline & RAF & $288 \pm 73$ & $319 \pm 199$ & $294 \pm 91$ & $277 \pm 84$ & $282 \pm 88$ & $319 \pm 53$ \\
\hline & RVR & $0.40 \pm 0.15$ & $0.30 \pm 0.24$ & $0.32 \pm 0.13$ & $0.32 \pm 0.13$ & $0.33 \pm 0.14$ & $0.32 \pm 0.09$ \\
\hline & FHR & $170 \pm 12$ & $166 \pm 13$ & $177 \pm 18$ & $178 \pm 16$ & $181 \pm 14$ & $175 \pm 12$ \\
\hline & FAP & $45 \pm 9$ & $45 \pm 8$ & $45 \pm 8$ & $45 \pm 11$ & $45 \pm 13$ & $46 \pm 12$ \\
\hline
\end{tabular}


Tab. III. Blood flow and resistance in a main uterine artery and an umbilical artery in normotensive ewes after intravenous administration of $300 \mathrm{mg}$ of Diazoxide, expressed as a percentage of control values (mean \pm S.D.).

\begin{tabular}{llccccc}
\hline \multicolumn{7}{c}{ Minutes after administration of diazoxide } \\
\cline { 3 - 7 } & & $0-5$ & $6-10$ & $11-35$ & $36-60$ & $61-100$ \\
\hline without plasma & UtAF & $66 \pm 15$ & $55 \pm 26$ & $47 \pm 13$ & $62 \pm 16$ & $78 \pm 20$ \\
expander (n=6) & UtVR & $107 \pm 29$ & $117 \pm 57$ & $117 \pm 25$ & $130 \pm 11$ & $108 \pm 6$ \\
& UmAF & $83 \pm 20$ & $102 \pm 48$ & $94 \pm 39$ & $76 \pm 8$ & $70 \pm 8$ \\
& UmVR & $123 \pm 47$ & $113 \pm 64$ & $104 \pm 60$ & $116 \pm 8$ & $136 \pm 24$ \\
with plasma & UtAF & $91 \pm 18$ & $96 \pm 11$ & $98 \pm 8$ & $85 \pm 8$ & $88 \pm 4$ \\
expander (n=4) & UtVR & $106 \pm 20$ & $98 \pm 11$ & $91 \pm 8$ & $101 \pm 15$ & $105 \pm 6$ \\
& UmAF & $99 \pm 2$ & $102 \pm 6$ & $104 \pm 11$ & $104 \pm 10$ & $87 \pm 20$ \\
& UmVR & $101 \pm 2$ & $98 \pm 7$ & $100 \pm 11$ & $93 \pm 9$ & $116 \pm 26$ \\
\hline UtAF & Uterine Artery Flow & & & UmAF Umbilical Artery Flow & \\
UtVR Uterine Vascular Resistance & & & UmVR Umbilical Vascular Resistance
\end{tabular}

tensive ewe showed a small and non-significant decrease, and maternal heart rate increased (Tabs. I and II). In the hypertensive ewes, however, there was a significant drop in mean arterial pressure to $80-85 \%$ of control values, which lasted at least one hour. The fall in arterial pressure was significantly less than that obtained with diazoxide without plasma expansion. Maternal heart rate showed a significant, in some animals twofold, increase which lasted at least two hours. In the

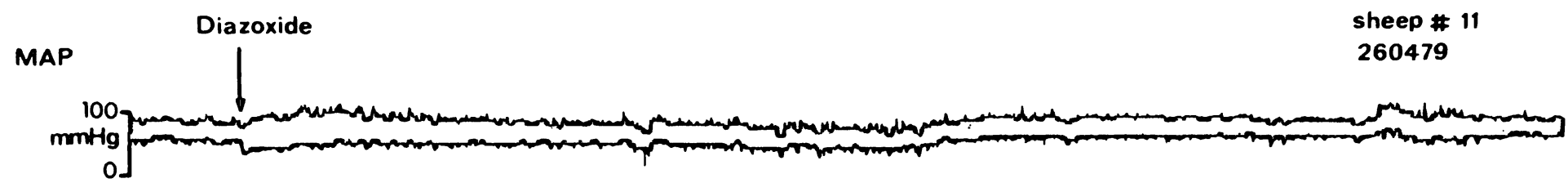

MRAF

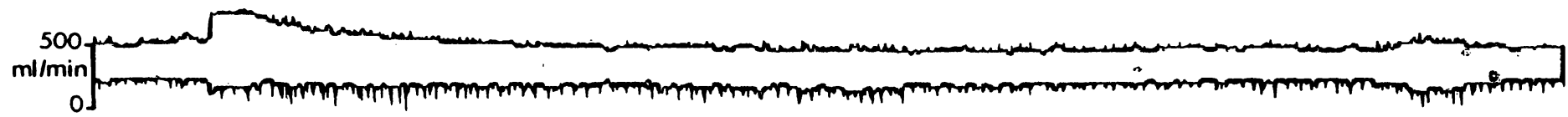

MUAF

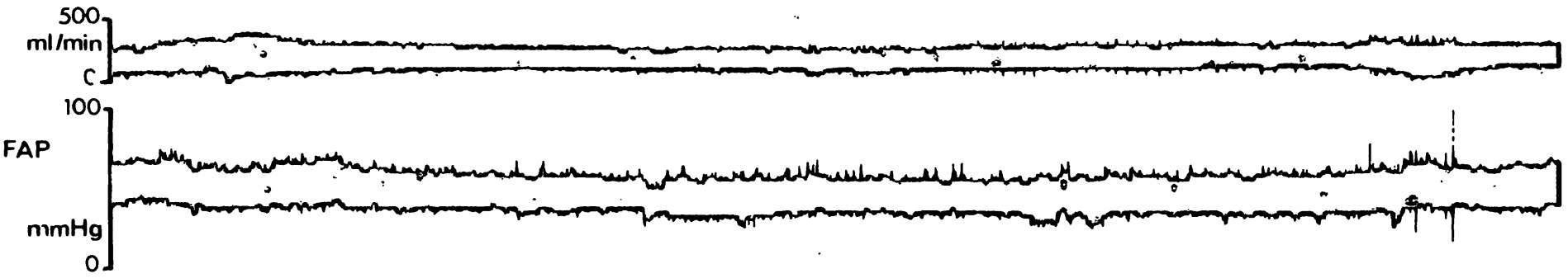

UAF

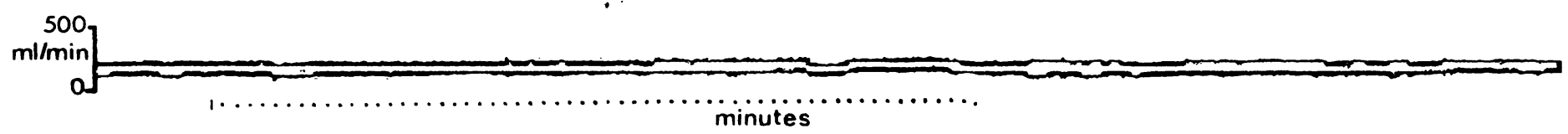

Fig. 1. Intravenous bolus injection of $30 \mathrm{mg}$ of diazoxide with plasma expansion in a normotensive ewe. Effects on maternal arterial pressure (MAP), renal artery flow (MRAF), uterine artery flow (MUAF), fetal arterial pressure (FAP), and umbilical artery flow (UAF). 
Tab. IV. Blood flow and resistance in a main uterine artery and an umbilical artery in hypertensive ewes after intervenous administration of $300 \mathrm{mg}$ of Diazoxide, expressed as a percentage of control values (mean \pm S.D.).

\begin{tabular}{|c|c|c|c|c|c|c|}
\hline & & Minutes a & Iministratio & iazoxide & & \\
\hline & & $0-5$ & $6-10$ & $11-35$ & $36-60$ & $61-110$ \\
\hline $\begin{array}{l}\text { without plasma } \\
\text { expander }(n=8)\end{array}$ & $\begin{array}{l}\text { UtAF } \\
\text { UtVR } \\
\text { UmAF } \\
\text { UmVR }\end{array}$ & $\begin{aligned} 66 & \pm 10 \\
95 & \pm 17 \\
101 & \pm 9 \\
103 & \pm 2\end{aligned}$ & $\begin{aligned} 47 & \pm 10 \\
115 & \pm 28 \\
90 & \pm 8 \\
115 & \pm 17\end{aligned}$ & $\begin{aligned} 68 & \pm 24 \\
111 & \pm 28 \\
103 & \pm 6 \\
109 & \pm 31\end{aligned}$ & $\begin{aligned} 93 & \pm 15 \\
99 & \pm 16 \\
113 & \pm 13 \\
97 & \pm 9\end{aligned}$ & $\begin{aligned} 79 & \pm 13 \\
90 & \pm 6 \\
109 & \pm 11 \\
100 & \pm 20\end{aligned}$ \\
\hline $\begin{array}{l}\text { with plasma } \\
\text { expander }(n=9)\end{array}$ & $\begin{array}{l}\text { UtAF } \\
\text { UtVR } \\
\text { UmAF } \\
\text { UmVR }\end{array}$ & $\begin{aligned} 106 & \pm 25 \\
87 & \pm 15 \\
113 & \pm 21 \\
96 & \pm 16\end{aligned}$ & $\begin{aligned} 104 & \pm 29 \\
86 & \pm 18 \\
108 & \pm 22 \\
93 & \pm 16\end{aligned}$ & $\begin{array}{r}98 \pm 36 \\
92 \pm 30 \\
106 \pm 19 \\
89 \pm 21\end{array}$ & $\begin{aligned} 103 & \pm 32 \\
92 & \pm 23 \\
105 & \pm 28 \\
94 & \pm 25\end{aligned}$ & $\begin{aligned} 95 & \pm 22 \\
89 & \pm 13 \\
100 & \pm 8 \\
102 & \pm 16\end{aligned}$ \\
\hline
\end{tabular}

normotensive as well as the hypertensive animals renal blood flow showed a tendency to increase during the first 10 minutes following administration of diazoxide, but the change was not significant. A striking increase in systolic-diastolic flow difference, was observed in all animals (Fig. 1 and 2). In both groups renal vascular resistance showed a significant fall which lasted at least one hour.

Mean uterine blood flow and resistance showed no significant changes in normotensive animals. In the hypertensive group, however, administration

MAP

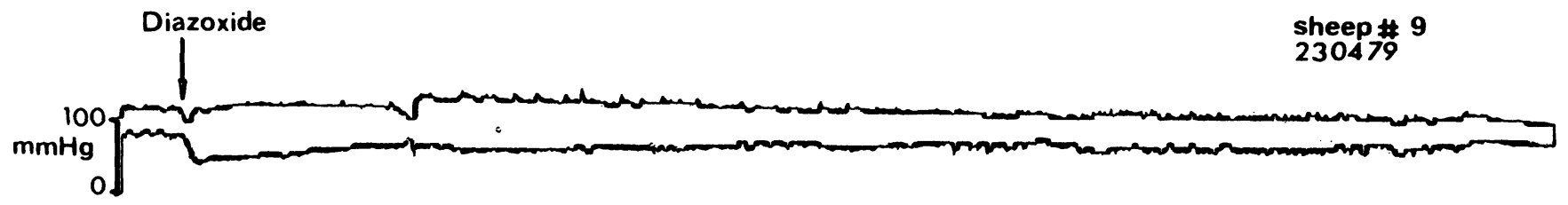

MRAF

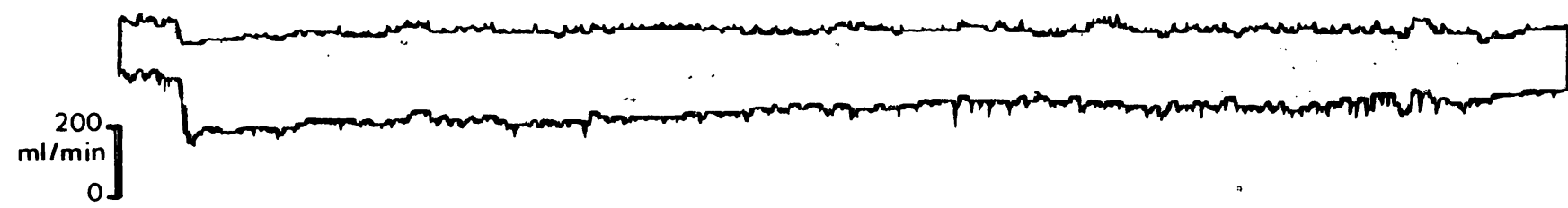

MUAF

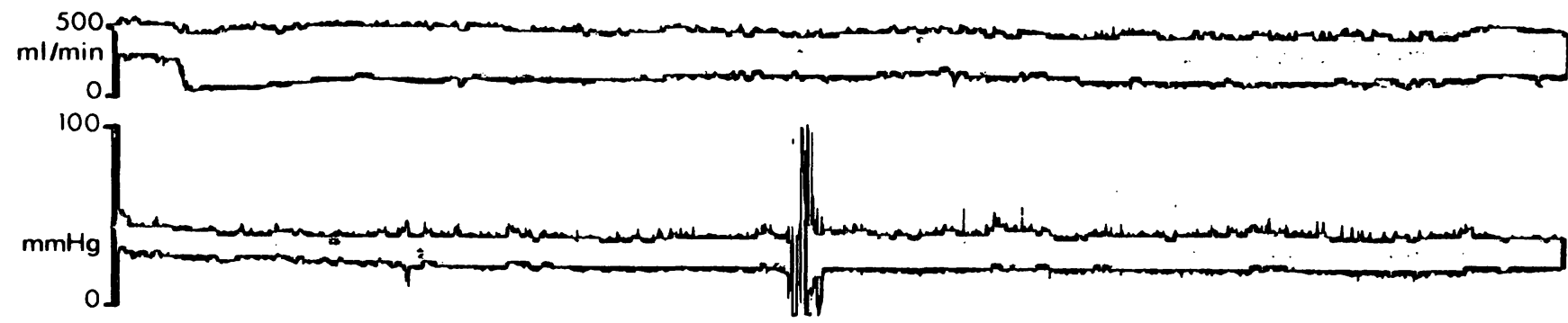

UAF

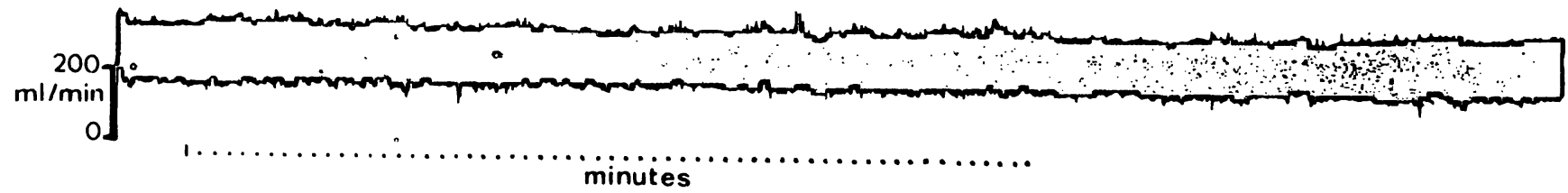

Fig. 2. Intravenous bolus injection of $300 \mathrm{mg}$ of diazoxide with plasma expansion in a hypertensive ewe. Abbreviations as in Fig. 1. 
of diazoxide combined with plasma expansion was followed in the first 10 minutes by a significant drop in uterine vascular resistance in the presence of an unaltered or even increased blood flow in the uterine artery (Tabs. III and IV).

In both groups no significant changes were observed in fetal heart rate or fetal arterial pressure, nor in blood flow and resistance in the umbilical artery. Fetal $\mathrm{pH}$ and $\mathrm{pO}_{2}$ values at 30 and 120 minutes remained stable.

\section{Discussion}

The chronically instrumented one-kidney hypertensive sheep model used in this study shows some pathophysiologic features of pregnancyinduced hypertension as it occurs in humans: an elevated blood pressure with an increased uterine vascular resistance [7]. These findings are in agreement with data reported by BRINKMAN [5] and can be attributed, at least initially, to an increased production of renin by the ischemic kidney [3]. Maintenance of the elevated arterial pressure is supposed to depend on volume expansion, increased cardiac output, and increased peripheral resistance not caused by increased plasma renin activity [3]. Our experiments do not allow any conclusion about these mechanisms, since plasma renin activity, plasma volume, and cardiac output were not measured. However, the significantly elevated maternal heart rate in the hypertensive ewes is compatible with the presence of a hyperdynamic circulation. This would certainly constitute a major difference with human pregnancy complicated by preeclampsia in which intravascular volume is usually contracted [27] and cardiac output is low [11].

The experiments demonstrate that bolus injection of diazoxide without simultaneous plasma expansion in normotensive and hypertensive pregnant ewes causes a rapid and protracted fall in mean arterial blood pressure, with a concomitant fall in renal and uterine blood flows. Accepting that the fall in arterial blood pressure is due to dilatation of peripheral resistance vessels [13], diazoxide appeared to have no dilating effect on the renal and uterine vasculature. In fact, in many experiments, in particular in group $\mathrm{NH}$, uterine vascular resistance increased, because the decrease in uterine blood flow was proportionately greater than the fall in blood pressure. In normotensive ewes these observations are in agreement with findings reported by others $[6,21]$, and could be explained by the fact that uterine vessels in pregnant sheep are normally widely dilated and function at maximum hemodynamic capacity, with a very limited potential for further decrease in vascular resistance [10]. For this reason, there appears to be no effective autoregulation of the uterine circulation by a further decrease in vascular resistance in response to a decreased perfusion pressure [29]. In addition, the acute hypotension following administration of diazoxide, due to systemic vasodilation with an increase in vascular capacity resulting in a fall in effective circulating blood volume, may lead to pathophysiologic mechanisms which are known to be operative in circulatory shock, in particular catecholamine release. This would explain the observed increase in uterine vascular resistance, since in sheep marked uterine vasoconstriction has been shown to occur with even minor alpha-adrenergic stimulation [26]. This hypothesis is supported by our finding that the demonstrated fall in uterine blood flow in normotensive ewes caused by a bolus of diazoxide can be prevented by simultaneous plasma expansion. Volume expansion will abolish the acute fall in effective circulating blood volume and thus prevent secondary catecholamine release. Also slow infusion of diazoxide has been reported to cause no changes in uterine blood flow in normotensive sheep, even in the face of markedly reduced arterial pressures [6], most likely because gradual endogenous volume shifts prevent the acute reduction in effective circulating blood volume which occurs following bolus injection.

In hypertensive ewes diazoxide combined with plasma expansion appeared to significantly reduce the elevated uterine vascular resistance, resulting in a stable or even increased uterine arterial blood flow. Diazoxide apparently does have a vasodilator effect on uterine vasculature which is not maximally dilated, provided that circulating volume is maintained.

It should be noted that in these experiments central venous pressure was not measured. For 
that reason we used the mean arterial pressure and not the actual perfusion pressure to calculate vascular resistances. Volume expansion may have caused an increase in venous pressure. Therefore, in volume expanded. animals true vascular resistances even may have been somewhat lower than the resistances calculated on the basis of mean arterial pressures alone.

Administration of diazoxide was accompanied in both groups by a significant and rather protracted increase in maternal heart rate. Plasma expansion appeared to have no influence on the maternal cardioacceleration and experiments by others indicate that it cannot be inhibited by betaadrenergic receptor blockade [19]. A 40-50 per cent rise in maternal heart rate is also reported to occur in preeclamptic patients treated with an intravenous bolus of diazoxide and has been attributed to a baroreceptor induced reflex tachycardia $[8,18,25]$. The observation that tachycardia also occurred in group $\mathrm{NH}$, where diazoxide with plasma expansion had virtually no effect on arterial blood pressure, suggests that diazoxide could also have a direct positive chronotropic effect on the maternal heart.

Before and between experiments the renovascular hypertensive state appeared to cause no fetal distress: All fetal variables determined in the control period in hypertensive ewes were comparable with those obtained in normotensive controls. The fall in uterine blood flow caused by a bolus injection of diazoxide without plasma expansion was accompanied by moderate fetal hypoxia with a decrease in fetal $\mathrm{pH}$, although overt fetal acidosis did not occur. These findings are in agreement with those reported by others $[6,16]$ and support existing experimental evid- ence that the healthy sheep fetus can tolerate a marked reduction in uterine blood flow without signs of compromise [10]. However, it seems likely that the transient fetal hypoxia must be held responsible for the observed fall in fetal heart rate which, under these circumstances, will result in a fall in combined ventricular output [22]. Since in our experiments umbilical flow remained rather stable, important redistribution of fetal blood flows must have occurred, favoring the placenta. Against the background of this data it can be understood that, if the fetus is already acidotic, a diazoxide-induced reduction in uterine blood flow may result in progressive fetal deterioration [16]. In both groups of experimental animals plasma expansion appeared to prevent any effect of an intravenous bolus of diazoxide on fetal oxygenation and acid-base status, most likely because uterine blood flow was maintained or even increased in the face of a marked reduction in mean arterial pressure.

In conclusion, the results of the present experimental study support the clinically demonstrated efficacy of an intravenous bolus of diazoxide in lowering maternal blood pressure in hypertensive pregnancy. Although we recognize the dangers and limitations of extrapolating our data to preeclampsia in human pregnancy, it is conceivable that fetal distress reported to occur following bolus injection of diazoxide in preeclamptic patients $[20,23]$ is due to a fall in uteroplacental blood flow, which may be prevented by plasma expansion. In preeclamptic patients the decrease in effective circulating volume following diazoxide may even be expected to be more pronounced than in one-kidney hypertensive ewes, because of the contracted plasma volume in this condition.

\section{Summary}

Diazoxide is a potent antihypertensive agent due to its peripheral vasodilator action. For this reason it is used in the management of hypertensive crises in pregnancy. To assess the effects of an intravenous bolus injection of diazoxide on maternal and fetal hemodynamics an experimental study was performed in 11 chronically instrumented pregnant sheep. In six ewes hypertension was induced by surgical removal of one kidney and reduction of arterial blood flow to the remaining kidney (onekidney renovascular hypertension). The other five ewes

remained normotensive. In a second operation, one week after the first one, the animals were equipped with electromagnetic flow transducers and catheters for monitoring of blood flow in a renal, a uterine, and an umbilical artery and for measurement of maternal and fetal arterial blood pressures, and blood sampling. Maternal heart rate was derived from the arterial pressure curve, fetal heart rate from a fetal ECG. Experiments were begun on the third day after the second operation. In each experiment a bolus of $300 \mathrm{mg}$ of diazoxide was 
administered intravenously, with or without rapid simultaneous infusion of $500 \mathrm{ml}$ of a plasma expander. A total of 17 experiments were performed in the one-kidney hypertensive ewes (Group H), nine with and eight without plasma expander. In the five normotensive animals (Group NH) 10 experiments were done, four with and six without plasma expansion. During the control periods maternal arterial pressure was approximately $30 \mathrm{~mm} \mathrm{Hg}$ higher in Group H than in Group NH. In Group $\mathrm{H}$ also maternal heart rate, and renal and uterine vascular resistances were significantly elevated. All fetal variables were equal in both groups. Administration of diazoxide without simultaneous plasma expansion resulted in both groups in a significant fall in maternal arterial pressure, a rise in maternal heart rate, and a fall in uterine and renal blood flows with a rise in vascular resistance. Fetal arterial pressure and umbilical blood flow showed no significant changes, but fetal heart rate showed a transient fall together with a drop in fetal $\mathrm{pO}_{2}$ and $\mathrm{pH}$, although acidosis did not occur. When diazoxide was combined with a plasma expander maternal blood pressure did not change significantly in Group NH, but fell in Group H. Maternal heart rate rose significantly in both groups. The decrease in uterine and renal blood flows which occurred when diazoxide was given without plasma expansion was not observed. In particular in Group $\mathrm{H}$ renal and uterine vascular resistances showed a significant fall. Fetal variables showed no change. These results indicate that diazoxide is a potent vasodilator, and that its circulatory effects are dependent on the maintenance of an effective circulating blood volume. Administration of an intravenous bolus of diazoxide leads to a sudden rise in vascular capacity with a decrease in effective circulating volume resulting in a fall in renal and uterine blood flows. The decrease in uteroplacental perfusion can be compensated by a healthy but most likely not by an acidotic fetus. These undesirable effects of diazoxide are prevented by simultaneous plasma expansion. It is concluded that the adverse effects of diazoxide on the fetus reported in preeclamptic patients may be due to the experimentally demonstrated fall in uteroplacental blood flow, which may be prevented by simultaneous plasma expansion.

Keywords: Experimental hypertension, diazoxide, Goldblatt-hypertension, volume expansion.

\section{Zusammenfassung}

Mütterliche und fetale Kreislaufwirkungen nach Diazoxid bei normotensiven und hypertensiven trächtigen Schafen Diazoxid gilt wegen seiner peripheren vasodilatatorischen Wirkung als potentes Antihypertensivum. Aus diesem Grund wird es auch bei hypertensiven Krisen in der Schwangerschaft angewandt. Um die hämodynamischen Auswirkungen eines intravenösen Diazoxidbolus sowohl auf die Mutter wie auf den Feten zu erfassen, wurde eine experimentelle Studie an 11 dauerüberwachten trächtigen Schafen durchgeführt. Bei 6 Schafen wurde der Hypertonus durch die Nephrektomie einer Niere und Reduktion des arteriellen Zuflusses der verbleibenden Niere induziert (renovaskulärer Hypertonus bei einer Niere). Die anderen 5 Schafe waren normotensiv. In einer zweiten Operation nach einer Woche wurden die Tiere mit elektromagnetischen Transducern und Kathetern zur Messung und Überwachung des renalen, uterinen und umbilikalen Blutflusses sowie des maternalen und fetalen arteriellen Blutdrucks versehen. Auch Blutentnahmen waren auf diesem Weg möglich. Die maternale Herzfrequenz leiteten wir aus der arteriellen Druckkurve ab, die fetale Frequenz aus dem ECG. 3 Tage nach der zweiten Operation haben wir mit den Experimenten begonnen. Dabei wurden jeweils $300 \mathrm{mg}$ Diazoxid intravenös verabreicht, zum Teil unter gleichzeitiger, rascher Infusion von $500 \mathrm{ml}$ Plasmaexpander. Insgesamt wurden in dem hypertensiven Kollektiv (Gruppe H) 17 Versuche durchgeführt, davon 9 mit und 8 ohne Plasmaexpander. Bei den 5 normotensiven Schafen (Gruppe NH) wurden 10 Experimente durchgeführt, davon $4 \mathrm{mit}$ und 6 ohne Plasmaexpander. Während der Kontrollperioden lag der artierielle Druck in der Gruppe $\mathrm{H}$ um etwa $30 \mathrm{mmHg}$ höher als in der Gruppe NH. Auch die maternale Herzfrequenz sowie die renale und uterine Resistance waren in der Gruppe $\mathrm{H}$ signifikant erhöht. Die fetalen Parameter waren in den beiden Gruppen vergleichbar. Nach Gabe von Diazoxid ohne Plasmaexpander erfolgte in beiden Gruppen ein signifikanter Abfall des mütterlichen arteriellen Druckes, ein Anstieg der maternalen Herzfrequenz und ein Abfall des uterinen und renalen Flows bei Erhöhung des vaskulären Widerstands. Der fetale arterielle Druck und der umbilikale Flow zeigten keine signifikanten Veränderungen, die fetale Herzfrequenz sank jedoch vorübergehend zusammen mit einem Abfall des fetalen $\mathrm{pO}_{2}$ und $\mathrm{pH} \mathrm{ab}$, ohne daß eine Azidose auftrat. Bei gleichzeitiger Gabe von Plasmaexpander fiel der maternale, arterielle Druck in der Gruppe NH nach Diazoxid nicht ab, wohl aber in der Gruppe $\mathrm{H}$.

Hinsichtlich der mütterlichen Herzfrequenz kam es in beiden Gruppen zu einem signifikanten Anstieg. Es erfolgte kein Abfall des uterinen und renalen Flows wie er nach Gabe von Diazoxid ohne Plasmaexpander zu beobachten war. In der Gruppe $\mathrm{H}$ kam es zu einem signifikanten Abfall der renalen und uterinen Resistance. Die fetalen Parameter änderten sich nicht. Die Ergebnisse zeigen, daß Diazoxid ein potenter Vasodilatator ist, dessen Kreislaufwirkung von der Aufrechterhaltung des effektiv zirkulierenden Blutvolumens abhängt. Die Gabe eines intravenösen Diazoxidbolus führt zu einer plötzlichen Erweiterung der Gefäßkapazität und einem Abfall des effektiv zirkulierenden Volumens, was einen reduzierten renalen und uterinen Flow zur Folge hat. Die Einschränkung der utero-plazentaren Perfusion kann durch einen gesunden Feten kompensiert werden, nicht aber durch einen azidotischen Feten. Dieser unerwünschte Effekt des Diazoxids kann durch gleichzeitige Plasma- 
expanderinfusion verhindert werden. Wir schließen aus unseren Experimenten, daß nachteilige Wirkungen auf den Feten nach Einsatz von Diazoxid bei präeklamptischen Patientinnen, von den berichtet wurde, auf den experi- mentell nachvollzogenen Abfall des utero-plazentaren Flows zurückzuführen sind. Dieser Abfall kann durch Gabe von Plasmaexpander verhindert werden.

Schlüsselwörter: Diazoxid, experimenteller Hypertonus, Goldblatt-Hypertonus, Volumenauffüllung.

\section{Résumé}

Effets du diazoxide sur les circulations maternelles et fœtales chez les brebis gravides normotendues et hypertendues

Le diazoxide est un agent antihypertenseur puissant du fait de son action vasodilatatrice périphérique. Pour cette raison, on l'utilise dans le traitement des poussées hypertensives de la grossesse. On a réalisé une étude expérimentale sur 11 brebis gravides appareillées en continu pour déterminer les effets de l'injection intra-veineuse d'embols de diazoxide sur l'hémodynamique maternelle et fœtale. Chez 6 brebis, l'hypertension a été induite par l'exérèse chirurgicale d'un rein et par la réduction du flux sanguin artériel au rein restant (hypertension rénovasculaire sur rein unique). Les 5 autres brebis sont demeurées normotendues. Par une seconde intervention, une semaine après la première, les animaux ont été appareillés de capteurs de flux électromagnétiques et de cathéters pour surveiller le débit sanguin artériel rénal, utérin et ombilical, pour mesurer les pressions artérielles maternelles et fœtales et pour effectuer des prélèvements sanguins. On a déterminé le rythme cardiaque maternel à partir de la courbe de pression artérielle et le rythme cardiaque fotal à partir de l'E.C.G. fœtal. Les expérimentations ont débuté le troisième jour après la seconde intervention. Au cours de chaque expérience on a injecté en intra-veineux un ensemble de $300 \mathrm{mg}$ de diazoxide, avec ou sans perfusion simultanée rapide de $500 \mathrm{ml}$ d'un extenseur plasmatique. $\mathrm{Au}$ total, 17 expérimentations ont été réalisées chez les brebis hypertendues à rein unique (groupe $\mathrm{H}$ ), neuf avec extenseur plasmatique et huit sans. Dans le groupe des animaux normotendus (groupe $\mathrm{NH}$ ) on a réalisé 10 expérimentations, 4 avec expansion plasmatique et 6 sans. Pendant les périodes de controle, la pression artérielle maternelle était aproximativement plus élevée de $30 \mathrm{~mm}$ de $\mathrm{Hg}$ dans le groupe $\mathrm{H}$ que dans le groupe $\mathrm{NH}$. Egalement, dans le groupe $\mathrm{H}$, le rythme cardiaque maternel ainsi que les résistances vasculaires rénales et utérines étaient élevés de façon significative. Toutes les variables fœtales étaient équivalentes dans les deux groupes.
L'injection de diazoxide sans expansion plasmatique simultanée a entrainé dans chaque groupe une chute significative de la pression artérielle maternelle, une élévation du rythme cardiaque maternel et une diminution des débits sanguins utérin et rénal avec augmentation des résistances vasculaires. Il n'y a pas eu de modification significative de la pression artérielle fœtale ni du débit sanguin ombilical, mais le rythme cardiaque fœtal a présenté un ralentissement transitoire en même temps qu'apparaissait une baisse de la $\mathrm{pO}_{2}$ fœtale et du $\mathrm{pH}$ sans néanmoins apparition d'acidose. Lorsque l'injection de diazoxide a été associée à une expansion plasmatique maternelle, il n'y a pas eu de modification significative de la pression artérielle maternelle dans le groupe $\mathrm{NH}$, mais est apparue une chute dans le groupe $\mathrm{H}$.

Le rythme cardiaque maternel s'est élevé dans chaque groupe. On n'a pas observé la diminution des débits sanguins utérin et rénal survenue lorsque le diazoxide avait été administré sans expansion plasmatique. Les résistances vasculaires rénale et utérine ont montré une chute significative en particulier dans le groupe $\mathrm{H}$. Les paramètres fœtaux ne se sont pas modifiés. Ces résultats indiquent que le diazoxide est un vasodilatateur puissant et que ses effets circulatoires sont sous la dépendance du maintien du volume sanguin circulant. L'injection intraveineuse d'un embol de diazoxide entraine une élévation rapide de la capacité vasculaire avec une diminution du volume circulatoire effectif entrainant une chute du débit sanguin rénal et utérin.

La diminution de la perfusion üéro-placentaire peut être compensée par un fœtus en bonne santé, mais vraissemblablement pas par un fœtus en acidose. Ces effets indésirables du diazoxide sont évités par une extension plasmatique simultanée. On en conclut que les effets nocifs du diazoxide sur le fœtus rapportés chez des patientes prééclemptiques peuvent être secondaires à la chute démontrée expérimentalement du débit sanguin utéro-placentaire, chute qui peut être évitée par une extension plasmatique simultanée.

Mots-clés: Diazoxide, extension volumétrique, hypertension de Goldblatt, hypertension expérimentale.

\section{Bibliography}

[1] BARR, P.A., E.D.M.GALLERY: Effect of diazoxide on the antepartum cardiotocograph in severe pregnancy-associated hypertension. Aust. N.Z. J. Obstet. Gynaecol. 21 (1981) 11

[2] BERMAN, W., R. C. GOODLIN, M. A. HEYMANN, A. M. RUDOLPH: Measurement of umbilical blood flow in fetal lambs in utero. J. Appl. Physiol. 39 (1975) 1056.

[3] BIANCHI, G. L., L. T. TENCONI, R. LUCCA: Effect in the conscious dog of constriction of the renal artery to a sole remaining kidney on hemodynamics, sodium balance, body fluid volumes, plasma renin 
concentration and pressor responsiveness to angiotensin. Clin. Sci. 38 (1970) 741

[4] BOUlos, D. N., L. E. DAVIS, C. H. ALMOND: Placental transfer of diazoxide and its hazardous effect on the newborn. J. Clin. Pharmacol. 11 (1971) 206

[5] BRINKMAN, C. R.: Experimental renal hypertension in pregnant sheep. II Response to a one-kidney model. Am. J. Obstet. Gynecol. 141 (1981) 895

[6] CARITIS, S., H. O. MORISHIMA, R. I. STARK, L. S. JAMES: The effect of diazoxide on uterine blood flow in pregnant sheep. Obstet. Gynecol. 48 (1976) 464

[7] CHESLEY, L. C.: Hypertensive disorders in pregnancy. Appleton-Century-Crofts, New York 1978

[8] DURING, R.: Klinische Erfahrungen bei der Behandlung der akuten Hochdruckkrise intra partum mit Diazoxid (Hypertonalum). Zbl. Gynäk. 104 (1982) 89

[9] FINNERTY, F. A.: Management of hypertension in toxemia of pregnancy. Hosp. Med. 11 (1975) 52

[10] GREISS, F. C. JR.: A clinical concept of uterine blood flow during pregnancy. Obstet. Gynecol. 30 (1967) 595

[11] GROENENDIJK, R., J. B. M. J. TRIMBOS, H. C. S. WALLENBURG: Hemodynamic measurements in severe preeclampsia. Clin. Exp. Hypertens. B.1 (1982) 287

[12] HAMBY, W. M., G. J. JANKOWSKI, J. M. POUGET, G. DUNCA, C. L. GANTT: Intravenous use of diazoxide in the treatment of severe hypertension. Circulation 37 (1968) 169

[13] KOCH-WESER, J.: Drug therapy: Diazoxide. N. Engl. J. Med. 294 (1976) 1271

[14] MCClEAN, A. B., J. R. DOIG, W. R. CHATFIELD, D. R. AICKIN: Small-dose diazoxide administration in pregnancy. Aust. N.Z. J. Obstet. Gynaecol. 21 (1981) 7

[15] MICHAEL, C. A.: Intravenous diazoxide in the treatment of severe preeclamptic toxemia and eclampsia. Aust. N.Z. J. Obstet. Gynaecol. 13 (1973) 143

[16] MORISHIMA, H. O., H. COHEN, W. U. BROWN, S. DANIEL, W. H. NEIMANN, L. S. JAMES: The inhibitory action of diazoxide on uterine activity in the subhuman primate: placental transfer and effect on the fetus. J. Perinat. Med. 1 (1973) 13

[17] MORISHIMA, H. O., S. N. CARITIS, M. N. YEH, L. S. JAMES: Prolonged infusion of diazoxide in the management of labor in the baboon. Obstet. Gynecol. 48 (1976) 203

[18] MORRIS, J. A., J.J. ARCE, C. J. HAMILTON, E. C. DAVIDSON, J. E. MAIDMAN, J. H. CLARK, R.S. BLOOM: The management of severe preeclampsia and eclampsia with intravenous diazoxide. Obstet. Gynecol. 49 (1977) 675
[19] MROCEK, W. J., W. R. LEE, M.E. DAVIDOV: Vasodilator administration in the presence of betaadrenergic blockade. Circulation 53 (1976) 985

[20] NEUMAN, J., B. WEISS, Y. RABELLO, L. CABAL, R. K. FREEMAN: Diazoxide for the acute control of severe hypertension complicating pregnancy: A pilot study. Obstet. Gynecol. 53 (1979) 505

[21] NUWAYHID, B., C. R. BRINKMAN, B. KATCHEN, S. SYMCHOWICZ, H. MARINEK, N. S. ASSALI: Maternal and fetal hemodynamic effects of diazoxide. Obstet. Gynecol. 46 (1975) 197

[22] PARER, J. T.: The effect of acute maternal hypoxia on fetal oxygenation and the umbilical circulation in the sheep. Eur.J. Obstet. Gynaecol. Reprod. Biol. 10 (1980) 125

[23] PERKINS, R. P.: Diazoxide in treatment of severe preeclampsia and hypertensive encephalopathy. Am. J. Obstet. Gynecol. 126 (1976) 296

[24] REDMAN, C. W. G.: The use of antihypertensive drugs in hypertension in pregnancy. Clin. Obstet. Gynecol. 4 (1977) 685

[25] RETZKE, U., R. SCHWARZ, W. LAUCKNER: Das hämodynamische Wirkungsprinzip von Diazoxid (Hypertonalum) bei der Behandlung akuter Hochdruckkrisen in Graviditate. Geburtsh. u. Frauenheilk. 39 (1979) 599

[26] ROSENFELD, C. R., J. WEST: Circulatory response to systemic infusion of norepinephrine in the pregnant ewe. Am. J. Obstet. Gynecol. 127 (1977) 376

[27] SOFFRONOFF, E.C., B. M. KAUFMANN, J. F. CONNAUGHTON: Intravascular volume determinations and fetal outcome in hypertensive diseases of pregnancy. Am. J. Obstet. Gynecol. 127 (1977) 4

[28] THIEN, TH., R.A.P.KOENE, CH.SCHIJF, G. F. F. M. PIETERS, T. K. A. B. ESKES, P. G. A. B. WIJDEVELD: Infusion of diazoxide in severe hypertension during pregnancy. Eur. J. Obstet. Gynaecol. Reprod. Biol. 10 (1980) 367

[29] WALLENBURG, H.C. S.: Modulation and regulation of uteroplacental blood flow. In: WALLENBURG, H. C. S., B. K. VAN KREEL, J. P. VAN DIJK: Transfer across the primate and non-primate placenta. W. B. Saunders Company Ltd, London 1981

Received October 5, 1983. Revised December 28, 1983. Accepted January 20, 1984.

Prof. Dr. H.C.S.Wallenburg Dept. of Obstetrics \& Gynecology AZR-Dijkzigt, Dr. Molewaterplein 40 3015 GD Rotterdam The Netherlands 
